\title{
Vegetation Database of the Hyrcanian Area
}

\author{
Alireza Naqinezhad
}

Abstract: The Hyrcanian (Caspian) area located in the north of Iran comprises a narrow band of temperate deciduous forests and is contiguous with a larger forest region extending through the Caucasus to eastern Turkey. These forests are covering the north-facing slopes of the Alborz mountain range and extend from the northwest to the northeast of Iran with an area of about $19,000 \mathrm{~km}^{2}$. Generally, the Hyrcanian area ranges from cool deciduous-lowland forests towards cool deciduous-mountain and timberline forests. The flora and vegetation of the Hyrcanian forests have been studied during the last half of century and comparative studies on the ecology of forest communities in the area are increasing. However, there is no comprehenisive database on the whole area. The Vegetation Database of the Hyrcanian Area (GIVD ID AS-IR-003) aims at providing a preliminary database for future comprehensive vegetation analysis.

Keywords: Caspian; Hyrcanian forest; relevé data.

GIVD Database ID: AS-IR-003

Last update: 2012-05-09

\section{Vegetation Database of the Hyrcanian Area}

Scope: The Caspian forests (Hyrcanian district) extend in an arc along the southern shore of the Caspian Sea from the Talysh region of Azerbaijan, NW Iran to the westernmost boundaries of Khorassan province, NE Iran. The area covers approximately 50,000 $\mathrm{km}^{2}$, located within the Iranian provinces Gilan, Mazandaran, and Golestan. It possesses a closed-canopy deciduous forest, unlike the arid to semi-arid landscape throughout most of Iran.

Status: emerging Period: $1964-2012$

Database manager(s): Alireza Naqinezhad (a.naqinezhad@umz.ac.ir)

Owner: Alireza Naqinezhad (private)

Web address: $[N A]$

Availability: [NA]

Database format(s): Excel

Publication: [NA]

Plot type(s): normal plots

Non-overlapping plots: 100

Total plot observations: 100

Countries: IR: $100.0 \%$

Forest: [NA] — Non-forest: [NA]

Guilds: all vascular plants: $100 \%$

Environmental data: [NA]

Performance measure(s): [NA]

Geographic localisation: [NA]

Sampling periods: [NA]

Information as of 2012-07-12; further details and future updates available from http://Www.givd.info/ID/AS-IR-003

Alireza Naqinezhad (a.naqinezhad@umz.ac.ir)

Department of Biology, Faculty of Basic Sciences, University of Mazandaran, Babolsar, IRAN. 